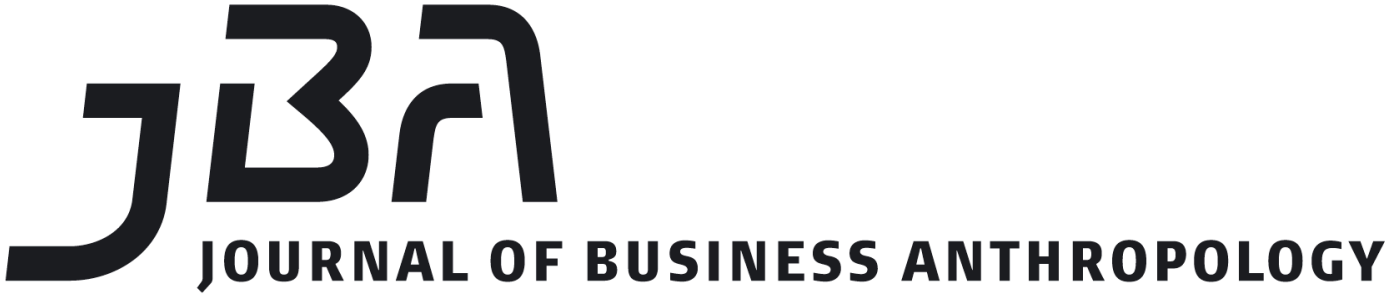

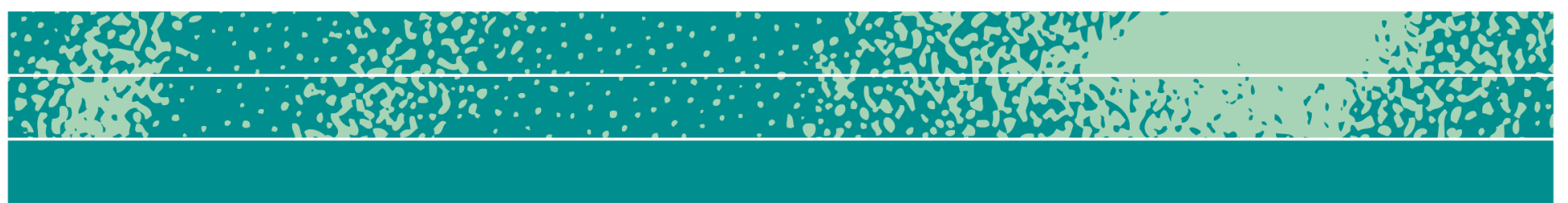

\section{Austerity Ireland, the New Thrift Culture and Sustainable Consumption}

Fiona Murphy

\begin{abstract}
In this article, I discuss whether austerity measures have an impact on individual consumers' orientations towards sustainability. Through an ethnographic examination of second-hand markets, in particular flea markets and second-hand baby goods markets, I examine whether economic crisis has changed people's consumption habits in Irish society. While the study of sustainability has a long, interdisciplinary history, little is known about the relationship between austerity and sustainable consumption patterns, particularly in an Irish context. Thus, this study questions whether reduced spending and consumption patterns may serve the interests of sustainability politics.
\end{abstract}

\section{Keywords}

Second-hand, thrift, sustainability, consumption, Ireland

\section{Page 1 of 17}

JBA 6(2): 158-174

Autumn 2017

(C) The Author(s) 2017

ISSN 2245-4217

www.cbs.dk/jba 


\section{Introduction}

A sign outside advertises in big bright letters that a second-hand baby goods market is taking place inside the church hall. A long line of people stand outside with children in tow, queuing up to be amongst the first to avail themselves of some of the better offers. The organisers had posted a long list on their Facebook page the previous evening, which highlighted the bargains. Expensive branded buggies and slings going for half their market price, clothes, toys, and all kinds of baby paraphernalia imaginable. The sellers inside are busy unpacking their goods, lining them up with homemade price tags. Some look anxious, parting not with material goods but with sets of memories of their first born or their last born, of the baby they struggled to have, of a phase of life they are happy to be over and done with; and so the stories go on. People chat and exchange tales about their baby goods, many find bargains and a story to be told in the buzz and excitement of the market (Field-notes 2013).

Paddy, an academic, artist, and self-ascribed 'greenie' sits opposite me on a stormy November afternoon telling me about how even in spite of substantial income cuts and an increase in taxes, he and his wife strive to live a 'sustainable life.' We sit together for hours sipping now cold tea, while he tracks his shopping habits, social life and aspirations to live in a world where what he calls a 'sustainability conscience' will permeate the everyday. Paddy's vast knowledge of food labels, the links between various corporations, and his political will to avoid the purchase of any produce coming from Israel astound me. In the midst of the conversation, I declare myself exhausted from listening to the organizing principles of Paddy's consumer life. The act of food shopping for Paddy takes place across days and in numerous kinds of food outlets. But Paddy, who some might deem radical, answers me: 'No, this is not exhausting; this is exciting. It is exciting to be able to live the life you dream everyone should aspire to.' Paddy's moral compass makes him a political consumer par excellence and his narrative of sustainable lifestyle embraces the nexus between social, political and cultural viewpoints embedded in larger sustainability projects (Field-notes 2013).

Post-Celtic-Tiger Ireland consumption spaces have changed considerably. Second-hand baby goods markets and flea markets, regular car boot sales, an increase in charity stores on city streets, community gardens, barter projects, the sharing economy and collaborative consumption practices have all proliferated since the beginning of Ireland's economic crisis. The journey from Ireland's boom time affluence to economic recession and austerity has shaped and altered consumption practices in significant ways. This article examines a possible link between austerity and sustainable consumption in the context of thrift shopping. Indeed, Ireland is a country that has experienced enormous change in recent years, moving from an affluent society (Celtic Tiger 
1993-2008) to a relatively impoverished and indebted one (Allen and O’Boyle 2013; Coulter and Nagle 2015; Keohane and Kuhling 2014).

The story of how Celtic Tiger Ireland came to be is one grounded in accelerated economic growth. Ireland was subject to a recession in the 1980s, which it overcame in the 1990s (Nolan, O'Connell and Whelan, 2000). The 1990s thus witnessed a period of rapid economic growth, including increases in wages and employment levels and housing prices. This set of developments produced what came to be known as the Celtic Tiger. While the manufacturing sector was responsible for early growth in the Celtic Tiger, a construction boom fueled the latter half resulting in a housing bubble and a dramatic crash in 2008 with the banking crisis. What followed from 2008 was a period of deep economic recession and austerity (Coulter and Nagle 2015). As such, 'Austerity Ireland' has become the shorthand descriptor for an Ireland subjected to both EU and nationally imposed fiscal retrenchment (Roche et al. 2016). Austerity Ireland is one where broad-ranging deficit-cutting, reduction of benefits, income inequality, cuts to public services and tax increases (but not with regard to corporate tax), emigration and an overall reduction in general spending has engendered widespread societal inequalities (Callen et al. 2013). Austerity is happening in the same moment that the environmental crisis is receiving increased attention (see Klein 2014). In fact, some commentators see particular links between austerity and environmental politics (see Bramall 2013; Hinton and Redclift 2009; Jensen 2013), a type of coupling of left and right politics which works to create a fantasy of frugal living as akin to sustainable living and, therefore, ultimately, as better for everyone. Andrew Simms (2001:4) calls this the,'environmental debt economy.'

Indeed, austerity in the context of this so called environmental debt economy (Simms 2001: 4) has become a site of discursive struggle (see Brammall 2013). On the one hand, we have notions of blame and responsibility where ordinary citizens are pilloried as 'wasteful' and 'greedy'; and, on the other, we have the idea that it is the ordinary citizen who, through frugal living, can propel us from crisis to recovery. One path chosen by at least some Irish citizens is to an imagined 'authentic' past; through austerity-induced frugal living, they hope to access the 'good life'. However, as Daniel Miller (1998 : 25) suggests, thrift can also mean simply buying more for less. It is not necessarily about second-hand shopping nor is it conducive per se to sustainable living. Indeed, Ireland's passive acceptance of austerity and visible lack of protest politics (with the recent exception of the water charge protests) has been highlighted, with some commentators positing the belief that Catholic values of austere living are also informing austerity Ireland (see Kenny 2012) ${ }^{1}$.

\footnotetext{
${ }^{1}$ See also the weekly protest by campaign group 'Dublin Says No' against austerity and water charges.
} 
'Austerity Ireland' has seen a change in how people not only consume but regard consumption (see Murphy and Mcdonagh 2016; Claudy, Keating and Prothero 2016). Coupled with the increase of secondhand shopping and community gardening, there has also been a visible, rapid expansion of stores such as Primark, Dealz, Aldi and Lidl, and, especially from 2008 to 2012, a decrease in consumer confidence and spending (see Lambkin 2016) ${ }^{2}$. Since 2008, Irish society has seen an increase in thrift culture with the proliferation of second-hand markets, charity and second-hand clothing stores, and community gardens (see Corcoran 2015). Much of this has stemmed from economic recession and austerity where partaking in thrift and second-hand culture has become a necessity. The benefits of engaging with second-hand and thrift cultures are widely celebrated within the austerity narrative; indeed many argue that austerity makes us more 'green and sustainable', and improves our overall well-being (see Soper 2013)

There are numerous positives to the emergence of this more visible second-hand and thrift culture in a post-Celtic Tiger Ireland. Soper (2013: 249) argues that austerity Ireland now has the space to 'denounce the puritanical and socially conservative aspects of traditional cultures of resistance to modernity, and argue for the importance of associating avant-garde social policy with a post-consumerist politics of prosperity,' with the potential to forge a new pathway to sustainable living. In contrast, Kim Humphrey (2010:188) argues that economic recession 'does not simply confirm anti-consumerist critiques, nor unproblematically move us towards anti-consumerist goals.' Gregson and Crewe (2006) similarly question the equation of second-hand culture with an ethics of sustainability.

The present article sits mid-way between these alternative premises. Through an analysis of the proliferation of second-hand 'baby goods markets' and flea markets in Ireland, I attempt to determine how individuals become committed to enacting sustainability practices in their everyday lives. I also explore whether the changes in consumption practices wrought by austerity impact how people view sustainability. Through an ethnographic analysis of second-hand markets, I assess how people's enactments and perceptions of sustainability are played out within these contexts, and later, in individual interviews garner their views on such. While the link between austerity and sustainability has been made in defence of austerity as a form of 'eco-austerity' (see Wells 2012), this study argues that no widespread engagement with sustainability is visible in spite of the re-emergence of a vibrant thrift culture in Ireland. The opening field-note depicts one of Ireland's newer baby good's markets as a site of emotion, colour and excitement where

\footnotetext{
${ }^{2}$ While data on consumer trends and confidence is easy to obtain, quantitative data on second-hand shopping is less available in an Irish context.
} 
people come to sell and buy, some experiencing for the first time a second-hand market. I juxtapose this with Paddy, a seasoned and committed self-identifying political consumer, who has a history of thinking about sustainability issues and associated political challenges. Both snapshots indicate how Irish consumption spaces (and the individuals within them) have experienced some degree of change during economic crisis; but both also point to how complex and varied are the understandings and commitments to sustainability.

\section{Background}

There is a very rich literature on second-hand cultures and sustainable consumption (too large a literature to cover in full, in fact), especially in anthropology (Wilk 2009; Miller 2012), geography (Gregson and Crewe 2006), and marketing (McDonagh and Prothero 2014). However, given the very recent history of the economic crisis, few studies make the link between sustainability, second-hand cultures and austerity/economic recession (see however, Murphy and McDonagh 2016).

Sustainable consumption and, indeed, the definition of sustainability itself is often characterized by conflicting and nebulous meanings and interpretations. Sustainability projects can be viewed in multiple and diverse ways - as a response to the growing climate of political fear, insecurity and risk (see also Beck 1992), a rational response to the ills of globalization and a growing body of knowledge about the "consequences of modernity" (Giddens 1990). As a concept, 'sustainability' is often reduced to the social, ecological and economic as a triple bottom line in business circles (Sachs 2015). It has widespread application in corporate, policy, and development worlds. The notion of sustainable development and broader understandings of sustainable consumption are most frequently linked to the UN Brundtland commission. In the commission's 1987 report called Our Common Future, sustainable development is defined as 'development that meets the needs of the present without compromising the ability of future generations to meet their own needs' (Brundtland 1987: 41). While this definition has been criticized, it is readily employed and rightly focuses on needs and justice. Sustainability is thus about intersections and connections-which industrial ecologist John Ehrenfeld and Andrew Hoffman (2013:6 ) sum up as: 'sustainability as flourishing'.

Sustainability has become part of a larger narrative around recovery from economic recession in Ireland (Murphy and McDonagh 2016). As a premise it can be seen as a way to link notions of ethics, responsibility and economic recovery (Murphy and McDonagh 2016). Indeed, in some instances sustainability has been reconstructed as a new justification for economic expansion (or sustainable capitalism), particularly with the growth in discourse around green economic 
recovery (Wells 2012). Large corporations now increasingly engage with sustainability (whether genuinely or as a form of greenwashing remains to be seen). Work on 'Smart cities' is also pushing the sustainability agenda, particularly within the technology industry (Kitchin 2014). On a smaller scale, in Ireland we see projects such as the Green Way (a cluster of Universities and companies striving to create a clean tech sustainable group of organisations) with the involvement of numerous Universities. At the community level, we have seen the growth of community gardens, the 'Grow it Yourself' movement (see Corcoran 2015), and various groups aiming to cultivate sustainable lifestyles. Individual consumers, such as Paddy, also strive to attain some form of sustainable lifestyle in their quotidian journeying towards a better future for the world.

There has been extensive work, particularly within anthropology and marketing (Holt 2012; Connolly and Prothero 2008; Jackson 2005), on understanding the motivations for sustainable consumption. However, sustainable consumers are far from being the mainstream (Evans 2011; Peattie 2001), and research on sustainable consumers in the context of austerity is only just emerging (Murphy and McDonagh 2016).

Kilbourne, McDonagh, and Prothero (1997) claim that ideas of sustainable consumption prove a challenge to the dominant social paradigm but within austerity politics this argument acquires a different hue. Other scholars construct sustainability discourse as an engagement with, indeed reflection of, neoliberal, market based policies, which engenders little more than 'elitist environmental submarkets and lifestyles' (Paavola 2001: 244). As such, the literature is permeated with a suspicion that at once masks and reveals the dynamics of power and responsibility embedded in sustainability projects whether at the individual, community, corporate or governmental level. This seeming ambiguity is undoubtedly a source of cleavage for the ethnographer attempting to address sustainable consumption. Debates within the literature are thus divisive: is it the planet that needs saving or the human life that lives on it (McDonagh and Prothero 2014)? Some scholars contend that sustainability should be a central concern for most western policy makers and citizens (Assadourian 2010; Belz and Peattie 2009) and that materialism has had detrimental impacts on the environment (Kilbourne et al. 1997) — although there have recently been calls for a new materialism that champions sustainability (Scott, Martin and Schouten 2014). Consumption is held in many regions to be a panacea for abject poverty, sometimes even seen as a nascent form of democratic participation, allowing freedoms where others are denied (Miller 2012; Slater 1997). Others construct 'environmentally friendly' consumption as one way to help reduce the negative impact of human activities on the natural environment (Robinot and Giannelloni 2009). These choices can include, for instance, reducing consumption levels by learning to 'identify those goods whose consumption adds little or nothing to welfare' (Reisch 
2001; 369), considering 'ecological and social criteria in the purchase, use and post-use of products' (Belz and Peattie 2009; 33), and registering 'political support or opposition through their shopping' (Nava 1991; 168). Others point out that sustainable consumption is a fallacy (Banbury, Stinerock and Subrhmanyan 2012).

The key focus of the present research is to investigate links between the re-emergence of a thrift culture in Ireland and sustainability in the context of austerity. While there are many studies which examine thrift or second-hand cultures in various contexts and, indeed, in its various iterations from garage sales to vintage clothes shops (see especially Gregson and Crewe 2006; Arnould and Bardhi 2005), few attempt to make an explicit link between austerity/crisis and sustainability ${ }^{3}$. Some key studies exist which examine the notion of sustainable consumption in second-hand contexts (see in particular Waight 2013). Others look (very importantly) at second-hand shoppers' motives; Guiot and Roux (2010: 366) outline an eight point motivation scale identifying the drivers for second-hand shopping-pricing appears as the first point and ethics/ecology as the fourth. A number of recent studies point to the connections between the sharing economy and economic crisis (see especially Ince and Hall 2017) and examine changing consumption practices due to economic crisis more broadly (see Claudy, Keating, and Prothero 2017). Scholars point to a decrease in the stigma once attached to second-hand shopping (certainly obvious in an Irish context) (see Franklin 2011); others argue that a visible increase in ethical and political consumption has occurred (Barendregt, Bart and Rivke Jaffe 2014).

Certainly, the findings in such studies indicate that investigating the connections between austerity, crisis, and sustainability in this particular social, economic and political context is both timely and important. Indeed, while there is disagreement in the literature on how sustainable consumption is viewed (McDonagh and Prothero 2014), the literature is nonetheless broad-ranging-marketing and the social sciences have produced important insights into the dynamics of sustainable consumption. Consumption research reveals an ongoing fascination with how sustainability discourse is shaping contemporary society, and such debates form the backdrop to my reflections in this piece.

\footnotetext{
${ }^{3}$ Studies from various disciplines examine a wide range of second-hand/thrift cultures-car boot sales, flea markets, charity stores, vintage stores, nearly new (baby) markets, swap shops, the sharing economy etc. I will not attempt to detail the vast literature on these topics in this piece, but merely flag its existence to indicate how rich and varied (and multidisciplinary), the interest is in this topic. Many of these studies mention links to environmental awareness or sustainability, but do not develop it as an explicit theme. Some of the better known studies took place before the global economic downturn, so do not make links between crisis and environmentalism; studies which do so are just emerging (Ince and Hall 2017).
} 


\section{Researching sustainability and thrift culture}

I am a second-hand shopping addict. Everything I'm wearing is secondhand! It was second-hand vintage style first, and then came an awareness of sustainability. I'm fashionable but I'm also doing something right for the environment. This is a big, big issue. (Second-hand shopper, Dublin flea market 2013).

I sell and I buy online and here, I do it partly because it's a good way of earning cash, but also because it's part of my value system. I am a greenie, I care about the world, and I want to encourage others through thrift. (Second-hand shopper and seller, Dublin flea market 2013).

Sustainability imaginaries are divergent; the political consumer may easily dismiss a particular corporation's attempt to construct sustainable corporate policy as merely 'green washing,' the corporation perhaps seeing their imaginary of sustainability as having much further reach than the citizen-consumer planting vegetables on his small allotment. Some green enthusiasts are more committed to sustainability through food networks, others through clothes or travel. Sustainability commitments vary greatly from individual to individual. Navigating such spaces, conflicts, and contradictions is a challenge for any ethnographer. The research for this project was based on an ethnographic analysis of flea markets, and second-hand baby goods markets over an 18 month period in Dublin, Cork and Kildare, Ireland. The markets are held in diverse areas, but many of the baby goods markets tend to take place in more affluent suburbs (usually in church halls or hotel function rooms). The researcher also conducted 20 qualitative semi-structured interviews with participants in these markets (both buyers and sellers) as well as individuals claiming to be sustainable or political consumers. Research participants were recruited through the second-hand markets as well as a number of sustainability organisations in Dublin. Interviewing selfconfessed sustainability advocates as well as individuals newly participating in second-hand culture offered an important comparative focus for the project in terms of levels of commitment and attitudes towards sustainability.

As previously indicated, sustainability as a term and mode of being is often ideologically reinterpreted at any given moment across sometimes conflicting arenas. Whether it exists in the form of soteriology (the technology will save us; smart and sustainable cities will arise), or as market environmentalism (Corporate Social Responsibility and trading policies), or in community gardens and second-hand markets, where individuals attempt to evolve a world compatible with their green conscience (aspirations for slow food, and the reassertion of the local), ethnography is a useful methodological tool for exploring sustainability movements. Austerity politics works to create a narrow vision of sustainable consumerism, and we need to be aware of how this is being 
encouraged in the context of broader sustainability politics. Such movements, viewed in terms of political governance, place the responsibility for sustainability on the individual consumer, thus absolving the State. These are the larger structural issues that scholarly research into sustainability must pay attention to, although they are beyond the scope of this article. As Paddy puts it, 'we must live green values otherwise this world will be lost. Our children will suffer. If we are waiting for the Irish state to do anything then it will be too late.' Indeed, understanding how and why my research participants started to live these so-called 'green values' is a key focus of this research.

\section{Second-hand markets and sustainability}

You got to preach to people, tell them, show them, look I look cool-the top is from a flea market and the rest of the stuff from charity. I did a thing last year where I didn't buy a piece of clothing for a year, but this year back into the second-hand spaces. Like I do this because it is the right thing to do. Like I constantly tell my friends that if we don't do something for the world, no one else will. (Second-hand shopper, Cork Flea market 2013).

It was a blustery November afternoon when I accompanied Sarah to a newly opened second-hand market sitting on a hilly street in Cork City. Sarah had been coming here since it opened, sometimes only to consume a cup of coffee, soak up the energy and vibes of the market and get to know, as she put it, some 'like-minded folk'. I was introduced to Sarah through Paddy, and after a few email exchanges, we agreed that the next time I was in Cork she would show me around some of the new second-hand markets appearing on the scene. While like Paddy, Sarah was a self-identifying green enthusiast, she promised to introduce me to people just beginning to engage with second-hand cultures and sustainability politics. With Sarah's help I met a number of regular frequenters of markets, both buyers and sellers.

When we entered the first market that we attended together, the first thing I noticed was the colour. As it had just opened as we were entering, it was extremely quiet, and we were the only customers, so Sarah and I decided to wander around before speaking to Emily the market organizer. To our left as we entered was a stall with antique style cups and household goods. In front of us, an elderly man sat reading a newspaper next to his bookstand. We glanced through his books, all being sold for a euro, and then took a tour around the market. Smallish in size (compared to the much larger Dublin flea market), the stalls were still full with a variety of items for sale, including clothing, books, household wares, memorabilia, vintage posters, postcards, and antique furniture-a veritable mish-mash of goods. We walked around to the coffee shop at the back of the market, where a young man with a beard and long hair tasked with being DJ smiled at us. After an interesting chat with the girls selling 
coffee, who told us they felt sustainability and being green was increasingly a fashionable orientation, Emily the market operator sat down with us. She told us that for Cork, Ireland's second largest city, a sustainability approach was important as the city would not move out of crisis as quickly as Dublin, the capital city. Emily also told us that sustainability was riddled with class complexity. She says:

Sustainability is a class thing. For working class people, it is often about just putting bread on the table. Sustainability rhetoric doesn't provide enough information for people in underprivileged areas to see the value of implementing it into their lives. However, markets like this provide an important space for people to learn the value of thrift or second-hand culture (Emily, Interview 2013).

One of Sarah's friends sat in on the conversation, and began to speak about how the class issue was really key in sustainability politics. Mary, who was a single mother at a young age, said she was only now 'waking up to second-hand culture':

I mean look at all these second-hand baby goods markets, like you would never have seen those in the boom. Everything new for a baby, it was utter madness, especially for the likes of myself, a single mother. What was I thinking? I clearly wasn't, new buggy, cot and so on, you get the picture. Now people seem to be much thriftier, much better at understanding that everything doesn't have to be new. (Mary, Interview 2013).

Mary invited us to attend the next second-hand baby market in Cork with her and one of her friends who had become a regular seller at such events. While Mary's friend Anita was 'in the business of selling at such events, she told me that most of the sellers were people wanting to empty their attics or closets of baby goods in order to earn some extra cash and also 'move on to the next phase of their lives.' Having conducted a number of interviews in more traditional flea markets, where I found people were more or less oriented towards the value of sustainability and second-hand shopping in their lives, I decided to speak to those involved in second-hand baby goods markets in order to get a sense of how people might be newly engaging with second-hand cultures and, potentially, sustainability. Anita told me that the sellers and buyers were very mixed in terms of their backgrounds, and that she herself had no particular interest in sustainability:

I do this to make some extra money, buying online, selling offline, I don't have any interest in sustainability, whatever that is exactly? (Anita, Interview 2013).

Anita, however, invited me to spend a day with her at one of her stalls in order to get a sense of the market and those attending. This was the first second-hand baby goods market that I attended and it gave me the opportunity to speak to a broad range of individuals. Generally, 
people told me that they were simply there for a bargain, that they thought it was a good idea and that they had no particular orientation towards sustainability. However, with a number of the sellers, views were somewhat different and this was replicated in a number of the markets that I attended. Frank, a parent and first time seller told me:

We try to recycle, teach our children the value of respecting the environment, and where possible we buy local food. I saw the sign for this and thought it was a brilliant idea. It ticks so many boxes and allows me to participate in a shopping space that is somewhat different. So far it's been great fun, and I'll come again with the rest of the stuff in our attic. (Frank, Interview 2013).

Jane, a mother of three and second time seller at a Dublin market also claimed to be oriented towards sustainability:

Actually it's only in the past year or so I have started to think more about this. We are now a one income family, I lost my job last year, and it's been a mixed blessing. We have started to think more about where we can cut our cloth. I came to this market a couple of months ago with some stuff and am back today to sell our final bits and pieces in the attic. The extra cash will be handy, but I have also met some interesting people and I am generally thinking that I need to shop more in charity stores and just think about the environment more. (Jane, Interview 2013).

Michael and Grainne, first time sellers, told me:

We have started to think a lot lately about climate change and being greener. I personally find the language of sustainability a bit alienating. I am never sure what it's all about, but I am more sure about green politics, whether it's the same thing or not-who knows? It's our first time selling here today but it's a cool place and we like the focus on second-hand. (M and G, Interview 2013).

So while some sellers did attribute a relationship between an interest in second-hand and sustainability or green values, many of the people I spoke to (most answered reluctantly) were primarily using the markets as a way of earning extra income. With this in mind, I decided to speak to the operators of the markets in order to get a sense of how they viewed those coming to sell and buy in their market.

The first second-hand baby good's market to launch in Ireland is called ARÍS (the Irish word for 'again'). ARÍS started operation in 2010 and is modelled after the British National Childcare Trust second-hand markets for baby goods. ARÍS has had great success and, since its opening, a number of other operators are now in business all across Ireland ${ }^{4}$.

${ }^{4}$ The ARIS quotes also appear in Murphy, F. (Forthcoming 2017). permission to 
The operator of ARÍS explains why she started the business:

There is a cultural thing of passing on in Ireland, which is totally acceptable, but with friends and families, not strangers. When I had the boys, even though it was in the Celtic Tiger, I didn't fall into the trap of buying everything new. I just want safe and clean. I don't care what version of bugaboo Gwyneth Paltrow is wheeling down Notting Hill. I don't like the online markets for baby goods because for babies it is all about touch, feel, smell. It is such a personal thing. The online baby shopping is not a model that works for me. When I set this market up in 2010 it was the first one in Ireland. I based it on the British National Childcare Trust model, and initially the idea was met with a somewhat muted response from people. (Interview with founder of ARÍS, Dublin, April 2013)

Similarly, the operator of another market says:

When I was pregnant, I had no intention of buying everything new. I shopped around online, but it is a pain. Like you want everything in the one place, just walk in and see what's there and buy it. It didn't exist in this area so I just set it up (Interview with baby market operator, Cork, March 2013)

Of significance in my interviews was that a number of the market operators noted that there has been a shift in the kinds of individuals attending the markets during the economic recession:

You can see that the profile of the sellers in particular has changed. When we first set up, the sellers were people who knew and understood market culture, people who were interested in sustainability etc., but as the crisis worsened then you would see people rock up who were selling because they really needed the money. I would tend to treat these sellers a little differently to the other types. You have to be sensitive, but you can see from the goods and the 2005 jeep that they arrive in what they used to have. I pay attention to these kinds of things (Interview with baby market operator, Dublin, May 2013).

We are booked out months in advance with our stalls, and the demand seems to be getting greater all the time. You can see the quality of stuff people are selling, it is great. But people are needing to sell this stuff more and more, you can see and it's sometimes surprising the kinds of people who show up (Interview with baby market operator, Cork, March 2013).

The market operators note that there has been a marked change in who is coming to sell and indeed, buy in their markets. While in

reproduce granted. 
attendance at the markets, I too noticed the very broad demographic at the baby good's markets. There was a reluctance (sometimes even embarrassment) on the part of some sellers to speak to me, particularly when it became clear that their main motive was to earn money. Those who were seasoned attendees and more oriented towards sustainability generally spoke to me at length.

I opened this section with a discussion between myself, Sarah, a committed sustainable advocate, and Emily, a flea market operator. Emily was particularly insistent that sustainability is a class issue, but in the context of economic crisis this is made even more complex. Consumers attend markets for all kinds of reasons, even with the goal of filling an otherwise boring Sunday afternoon with something different to do. Whatever the motives of second-hand shoppers, however, second-hand markets do offer the potential to better educate individuals in the value of sustainability. However, it is clear that not everyone shopping in these spaces has concerns about the environment, thus making broad links between thrift culture and sustainability complex.

\section{Conclusions}

While the majority of the people I interviewed were beginning to engage with the value of second-hand shopping and its links to broader global issues (Gregson and Crewe 2003), many of them had not thought formally about the issue of sustainability. It seems that second-hand baby goods markets are indeed a birthing ground for a deeper engagement with issues connected to sustainability; nonetheless many people foreground monetary reasons as their primary motive for attending the market. This appeared to be different in flea markets, where the majority of people I interviewed identified as sustainable or green consumers. Like Paddy, these were individuals whose lifestyle was oriented around sustainable, political or ethical consumption. The second-hand baby goods markets attract a much broader demographic and thus prove a more fertile ground for exploring whether economic crisis might precipitate a deeper engagement with sustainability for more mainstream consumers. The transient nature of these markets means that beyond repeat sellers and operators, it is challenging to measure whether an encounter with second-hand cultures in these kinds of markets might have a long term impact on more mainstream consumers. My research participants attended second-hand markets for a variety of reasons-bargain hunting and necessity, recreation, and some because they considered themselves sustainable/ethical consumers. In the main, I would argue that mainstream consumers attending second-hand baby goods markets get a 'taste' for second-hand cultures with a minority making the link to sustainability. There has been much talk about how enacting sustainability does not equate to widespread agreement around a 
particular articulation of what sustainability actually means. As such, it is clear that a number of my research participants enact sustainability without fully realising that that is their orientation. Ultimately, this research argues that while economic crisis creates a space for more sustainably oriented consumption practices, this will not have a long lasting impact without more widespread education about and policy regarding sustainability in Ireland. Austerity alone will not move us towards a place where sustainability figures importantly; only a more self-aware 'human economy' (Hart 2010: 2) will achieve this.

\section{References}

Allen, K. and O'Boyle, B. 2013 Austerity Ireland: the failure of Irish Capitalism. London: Pluto Press. https://doi.org/10.2307/j.ctt183p540

Arnould, E.J. and Bardhi, F. 2005 'Thrift shopping: combining utilitarian thrift and hedonic treat benefits.' Journal of Consumer Behaviour 4(4): 223-233 https://doi.org/10.1002/cb.12

Assadourian, E. 2010 'Transforming cultures: from consumerism to sustainability.' Journal of Macromarketing 30(2): 186-191. https://doi.org/10.1177/0276146710361932

Banbury, C. et al. 2012 'Sustainable consumption: introspecting across multiple lived cultures.' Journal of Business Research 65(4): 497-503. https://doi.org/10.1016/j.jbusres.2011.02.028

Barr, S. et al. 2011 'The policy and practice of 'sustainable lifestyles.' Journal of Environmental Planning and Management 54(10): 1331-1350. https://doi.org/10.1080/09640568.2011.574996

Barendregt, Bart and Rivke Jaffe (eds.). 2014 Green Consumption: The Global Rise of Eco-chic. London:

Bloomsbury. https://doi.org/10.5040/9781474214049

Beck, U. 1992 Risk Society: Towards a New Modernity. New Delhi: Sage.

Belz, F. and Peattie, K. 2009 Sustainability Marketing: A Global Perspective. West Sussex: John Wiley \& Sons.

Bramall, R. 2013 The Cultural Politics of Austerity: Past and Present in Austere Times. Basingstoke: Palgrave Macmillan. https://doi.org/10.1177/0267323114533046i

Coulter, C. and Nagle, A. (eds). 2015 Ireland under Austerity: Neoliberal Crisis, Neoliberal Solutions. Manchester: Manchester University Press.

Callan, T. et al. 2013 'The great recession, austerity and inequality: evidence from Ireland.' Intereconomics 48 (6): 335-338.

Connolly, J. and Prothero, A. 2008 'Green consumption: life-politics, risk 
and contradictions.' Journal of Consumer Culture 8(1): 117-45.

https://doi.org/10.1177/1469540507086422

Corcoran, M. and Kettle P. 2015 'Urban agriculture, civil interfaces and moving beyond difference: the experiences of plot holders in Dublin and Belfast.' Local Environment 20 (10):1215-1230. https://doi.org/10.1080/13549839.2015.1038228

Ehrenfeld, J. and Hoffman, A.J. 2013 Flourishing: A Frank Conversation about Sustainability. Redwood City, CA, USA: Stanford University Press.

Evans, D. 2011 'Thrifty, green or frugal: reflections on sustainable consumption in a changing economic climate.' Geoforum 42 (5): 550-557. https://doi.org/10.1016/j.geoforum.2011.03.008

Franklin, A. 2011 'The Ethics of Second Hand Consumption'. In T. Lewis and E. Potter (eds). Ethical Consumption: A Critical Introduction, pp. 156168. Oxon: Routledge.

Giddens, A. 1990 Consequences of modernity. Cambridge: Polity Press. Gregson, N. and Crew, L. 2003 Second Hand Cultures. Oxford: Berg. https://doi.org/10.2752/9781847888853

Guiot, D. and Roux, D. 2010 'A second-hand shoppers' motivation scale: antecedents, consequences, and implications for retailers.' Journal of Retailing 86(4): 355-371. https://doi.org/10.1016/j.jretai.2010.08.002 Hart, K. 2010 The Human Economy. UK: Polity Press Hinton, E. and Redclift, M. 2009 Austerity and Sufficiency: The Changing Politics of Sustainable Consumption. London: King's College London.

Holt, D. 2012 'Constructing sustainable consumption.' The ANNALS of the American Academy of Political and Social Science 644(November): 236255. https://doi.org/10.1177/0002716212453260

Humphery, K. 2010. 'The simple and the good: ethical consumption as anti-consumerism.' In T. Lewis and E. Potter (eds) Ethical Consumption: A Critical Introduction, pp. 40-53. London: Routledge.

Ince, A. and Hall, S.M. (eds.). 2017 Sharing Economies in Times of Crisis: Practices, Politics and Possibilities. Abingdon: Routledge.

Jackson, T. 2005 'Motivating sustainable consumption: a review of evidence on consumer behaviour and behavioural change.' Report to the Sustainable Development Research Network, accessed 24 July, 2013, available at:

http://www.sustainablelifestyles.ac.uk/sites/default/files/motivating_sc final.pdf.

Jensen, T. 2013 'Tough love in tough times.' Studies in the Maternal 4 (2), available at: http://www.mamsie.bbk.ac.uk/Jensen_SiM_4_2_2012.html. (January 19th 2016). https://doi.org/10.16995/sim.35 
Kenny, M. 2012 'Ireland faces a choice between lucre and liberty.' The Guardian, May $25^{\text {th }}$.

http://www.theguardian.com/commentisfree/2012/may/25/irelandfaces-choice-lucre-liberty-eu, accessed 13 August, 2015.

Keohane, K. and Kuhling, C. 2014 The Political, Domestic and Moral Economies of Post Celtic Tiger Ireland. Manchester: Manchester University Press. https://doi.org/10.7228/manchester/9780719091674.003.0010

Kilbourne, W. et al. 1997 'Sustainable consumption and the quality of life: a macromarketing challenge to the dominant social paradigm.'

Journal of Macromarketing 17: 4-24. https://doi.org/10.1177/027614679701700103

Kitchin, R. 2014 'The real-time city? Big data and smart urbanism.' GeoJournal 79(1): 1-14. https://doi.org/10.1007/s10708-013-9516-8

Klein, N. 2014 This Changes Everything. New York: Simon and Schuster. Lambkin, M. 2016 Consumer Market Monitor (Quarterly Report). Dublin: University College Dublin and Irish Marketing Institute.

McDonough, W. and Braungart, M. 2002 Cradle to Cradle: Remaking the Way we Make Things. North Point Press: New York.

McDonagh, P. and Prothero, A. 2014 'Sustainability marketing research: past, present and future.' Journal of Marketing Management 30(11-12): 1186-1219. https://doi.org/10.1080/0267257x.2014.943263

Miller, D. 2012 Consumption and Its Consequences. London: Polity Press.

Miller, D. 1998 A Theory of Shopping. UK: Cornell University Press.

Nava, M. 1991 'Consumerism reconsidered: buying and power.' Cultural Studies 5(2): 157-173. https://doi.org/10.1080/09502389100490141

Murphy, F and Mcdonagh, P. (eds). 2016 Envisioning Sustainabilities: Towards an Anthropology of Sustainability. Cambridge: Cambridge Scholars Publishing.

Murphy, F. (Forthcoming) 2017. 'The austerity myth: parenting and the new thrift culture in contemporary Ireland'. In Heffernan, E., MooreCherry, N. and McHale, J. Debating Austerity in Ireland. Dublin: Royal Irish Academy.

Nolan, B. et al. 2000 Bust to boom? The Irish Experience of Growth and Inequality. Dublin: IPA.

Paavola, J. 2001 'Towards sustainable consumption: economics and ethical concerns for the environment in consumer choice.' Review of Social Economy 59 (2): 228-248.

https://doi.org/10.1080/00346760122574

Peattie, K. 2001 'Golden goose or wild goose? The hunt for the green consumer.' Business Strategy and the Environment 10(4): 187-199. 
https://doi.org/10.1002/bse.292

Reisch, L. 2001 'Time and wealth: the role of time and temporalities for sustainable patterns of consumption.' Time and Society 10:367-385. https://doi.org/10.1177/0961463x01010002012

Robinot, E. and J. L. Giannelloni 2009 'Attitudes towards environmentally friendly hospitality management: a measurement scale.' Recherche et Applications en Marketing 24(2): 29-50. https://doi.org/10.1177/205157070902400202

Sachs, J. 2015 The Age of Sustainable Development. New York: Columbia University Press

Scott, K. et al. 2014 'Marketing and the new materialism.' Journal of Macromarketing 34(3): 282-290. https://doi.org/10.1177/0276146714532471

Simms, A. 2001 An Environmental War Economy. UK: NEF Foundation. Slater, D. 1997 Consumer culture and modernity. Cambridge: Polity Press. Soper, K. 2013 'The dialectics of progress: Irish 'belatedness' and the politics of prosperity.' Ephemera 13(12): 249-267.

United Nations. 1987 Our Common Future - Brundtland Report. UK: Oxford University Press.

Waight, E. 2014 'Second-hand consumption among middle-class mothers in the UK: thrift, distinction and risk.' Families, Relationships and Societies Vol.3(1): 159-162. https://doi.org/10.1332/204674313x13805551473134

Wells, P. E. 2012 The Automotive Industry in an Era of Eco-austerity: Creating an Industry as if the Planet Mattered. Aldershot: Edward Elgar. https://doi.org/10.4337/9781849807203

Wilk, R. 2009 'Consuming ourselves to death.' In Crate, S. (ed.) Anthropology and Climate Change: From Encounters to Actions, pp. 265276. Walnut Creek, CA: Left Coast Press, Inc.

William K. R., O'Connell,P.J. and Prothero, A. (eds). 2016 Austerity and Recovery in Ireland: Europe's Poster Child and the Great Recession. Oxford: Oxford University Press.

https://doi.org/10.1093/acprof:oso/9780198792376.001.0001

Fiona Murphy is a research fellow at the Senator George J. Mitchell Institute for Global Peace, Security and Justice in Queens University Belfast. Her research interests include sustainability, business anthropology, migration, and Indigenous rights. 